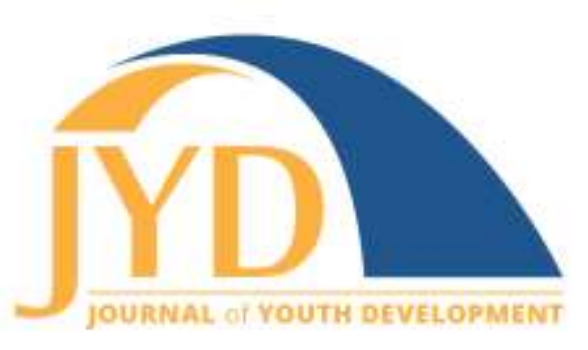

http://jyd.pitt.edu/ | Vol. 12 Issue 1 DOI 10.5195/jyd.2017.487 | ISSN 2325-4017 (online)

\title{
On Being Disrupted: Youth Work and Black Lives Matter
}

\author{
Angela Marie Bonfiglio \\ Redeemer Center for Life \& Redeemer Lutheran Church \\ North Minneapolis \\ NorthStar Youth Worker Fellowship \\ a.bonfiglio.31@gmail.com
}

\begin{abstract}
Youth workers are constantly figuring out how to respond to their young people, especially in times of disruption. The Black Lives Matter movement came close to home in the aftermath of the shooting by police of Jamar Clark, a young black man in north Minneapolis. This article is a reflection on the tensions that six area youth workers faced and the variety of roles that they played in working with their young people. The goal of this paper is to inspire other youth workers to be bold to act in times of disruption in order to support their young people and challenge the systems that impact them.
\end{abstract}

Over the course of history, social justice movements have created disruption to the dominant narrative in order change the perspective of the masses to a new narrative. Organizers of social movements create disruption through a number of tactics including protests, rallies, boycotts, and civil disobedience to bring attention to their narrative. Globally in the last century, we have seen many justice movements take center stage, including the Movement for Black Lives also known as Black Lives Matter (BLM).

As an individual who is passionate about equity and justice work, I see the importance of disruption in daily routine in order to agitate and demonstrate a new reality and bring voice to an otherwise silenced story. Yet, I am still navigating what this means as a youth worker. As a relatively new youth worker in north Minneapolis, issues of equity, race, and racism have always been the center of my work. As a white person in a diverse community, it has been an ongoing learning process in understanding racism and how I can be a part of undoing racism from where I stand.

(cc) EY New articles in this journal are licensed under a Creative Commons Attribution 4.0 License. This journal is published by the University Library System, University of Pittsburgh and is cosponsored by the University of Pittsburgh Press. The Journal of Youth Development is the official peer-reviewed publication of the National Association of Extension 4-H Agents and the National AfterSchool Association. 
In the aftermath of the killing of Trayvon Martin and Terrence Franklin, the reality continued to come closer to home, as young boys the same age or slightly older than many of my youth had been killed. The reality continued to sink deeper after the deaths of Michael Brown, Aiyana Jones, and Tamir Rice. The issue of violence against black bodies was a reality in which my community in north Minneapolis had a heightened awareness from the news, social media and movements in the lives of the young people. North Minneapolis residents are aware that the social ills of racism and inequality are embedded into many systems in our community, such as education, policing, employment, transportation and the judicial system.

In the aftermath of the death of Michael Brown, the BLM movement was becoming organized locally. A number of groups in the movement set out to shed light on the reality for black and brown people in Minneapolis and beyond. On November 15, 2015, in the heart of north Minneapolis, a place that historically has faced decades of disinvestment, decades of overpolicing, and decades of systematic racism and discrimination, Jamar Clark was shot by police officers. Less than 12 hours later, activists, community members, and family members gathered and organized to put pressure on the city, police, and county officials to act in response to the loss of a life through 18 days of occupation, protests, outreach, organizing and marches that took over the police precinct, highways, streets, and government buildings. As a community, we were organized to act in response to a tragic event that affected one of our own because many groups and organizations were already doing this work under the umbrella of a national movement.

During this time, especially during the 18-day occupation, I had serious questions related to my role as a youth worker. What are personal and professional boundaries that I must pay attention to? Is my organization supportive? As a staff member, what is my role in pushing for support in this time? As a white person, how do I engage my youth group of predominately black high schoolers in these conversations? In the faith development of young people, how do I respond to those experiencing loss? How are youth in my neighborhood processing this situation? Is it my role to encourage youth to be involved? How do I represent myself and my values? How are different youth workers across the metro area responding? What are the similarities and differences based on where they are located?

I have always been committed to action, but I questioned what action I would take personally and what action I would take in my professional role. In response to disruption, some of the 
actions I took were not calculated and they pushed beyond my normal role. I asked myself: How do I represent myself, my values, my organization and my youth? Less than a week after the shooting, my youth group was heading up to camp for a weekend retreat. At the end of the night during highs and lows, one of my youth said, "Please pray for our family; Jamar was my cousin". When we are in community, we have increased levels of response when personal connections exist. As a faith leader and a mentor, I have a support role in times of mourning and grief with young people. In this moment, I was reminded of the seriousness of my role as a youth worker and how close to home police brutality can come to my youth.

From taking time to sink into some of these pertinent questions in my context, I believe youth workers are in the position to respond when social justice movements create disruption to the dominant narrative by engaging young people in a variety of ways. The role that a youth worker takes depends on a number of factors including the identity and context of their own lived experiences, the identity and reality of their young people, and the position and role of the organizations they work for. At any point in time as a youth worker, we are navigating the conflict between whom we respond to and who we represent. Do we represent ourselves and our values? Do we work for our organization's values and priorities? Do we work for the youth in our community? This ultimately boils down to a tension that youth workers face in a number of situations, and I will use the current movement, Black Lives Matter, as a case study. Through context, theories and interviews with youth workers, this paper will present a discussion of the roles and tensions youth workers faced in responding to their young people between November 2015 and March 2016.

\section{Methodology}

I interviewed six youth workers whom I chose because they responded in some way in their professional role with youth, primarily ages 14 to 24 . They are traditional, paid youth workers who work within structured organizations: three work in a faith community, two work in community-based nonprofits, and one works within a school. I have not included the countless leaders of the different movements, school teachers, and informal mentors who have supported young people in their personal connection or involvement in the broader movement for black lives due to the constraints of this article, yet I recognize their large contribution. Throughout this article, I will reference quotes from the interviews I have collected. In order to maintain anonymity, identifying information has been removed, but in order to understand the work of these leaders, I will include brief descriptions of their contexts in order to follow their stories through the article. 


\section{The youth workers}

- Vera is a white youth director in a church in a suburban and rural setting in southern Minnesota. White youth and youth of color who have been adopted attend her youth group. Her youths' community is becoming more diverse as the demographics are changing in their schools.

- Nyame is a black youth worker from north Minneapolis who works at a regional organization in Minneapolis that focuses primarily on policy and grant-making with a commitment to racial equity. She has many roles at the organization, but mainly spoke to me about a group of Northside young people she works with doing research in their own community.

- Timothy is a white youth director in a suburb of Minneapolis who works at a church that is well known for being progressive. His youth are mainly white and attend both urban and suburban schools, where he sees a divide in his experiences.

- Stephanie is a youth director at a suburban church. She has youth that go to two different high schools, one being mostly white and the other being much more diverse in the same city. Like Stephanie, many of the youth she works with are white. While she lives in the city, she notices many ways in which her youth are disconnected from urban experiences.

- Nate works in a non-profit located in Minneapolis. His work is centralized in north Minneapolis, where he works primarily with north Minneapolis youth on employment and job readiness. Nate often commented that these were the youth that no one else is engaging. As a white youth worker, living in north Minneapolis, working primarily with black youth, he has learned much from his youth and from being in the north Minneapolis community.

- Candice is a youth worker in a school context. She works with young people of color from north Minneapolis in a south Minneapolis school as a coordinator and advisor. She works with students by hosting support groups throughout the school week and helps students navigate a high school with a majority white staff and students. As a black youth worker, she sees it as extremely important for her students to see someone that looks like them in the school environment.

Youth workers have the chance to engage with young people within the systems in which they live, go to school, and spend their out-of-school time in order to give young people the chance to try new opportunities and begin to understand responsibilities and their choices. I will use 
the interviews to show how youth workers are uniquely able to respond amidst disruption for positive impact and opportunity to engage with their youth in relationship to a social justice movement in a positive way.

\section{Social Movements Disrupt Status Quo}

Our lives are dictated by rules of work and patterns in our day-to-day existence that regulate our days, weeks and seasons. These patterns rule social institutions as well as individuals. When individuals or groups of people are pushed out of routine or act outside of social patterns, the stability of the social institutions in which they function is interrupted (Piven and Cloward, 1977). Thus movements begin and grow out of disruptions to the norms for groups of people that break down the social patterns and institutions. From these disruptions, ordinary people begin to try to make changes against nation states or powerful groups. Social networks contribute to an individual's ability to enact change. Sidney Tarrow (2011) calls this contentious politics, where "ordinary people-often in alliance with more influential citizens and with changes in public mood-join forces in confrontation with elites, authorities, and opponents....Contentious politics is triggered when changing political opportunities and constraints create incentives to take action for actors who lack resources on their own" (p. 6).

Not all situations of contentious politics are social movements. In order to have a social movement, these events of contentious politics must be supported by underlying social networks, the framing of a movement, and the capacity for ongoing challenges to the opponents' narratives. Necessary to all social movements are contentious collective actions, which can take the form of protests, strikes, riots, and revolutions in order that people who are underrepresented within institutions can "behave in ways to fundamentally challenge others or authorities" (Tarrow, 2011, p. 7). Movements are disruptive by definition against social groups or cultural codes. Disruption can look like "coordinated personal resistance or collective affirmation of new values" (Tarrow, 2011, p. 9). By this qualification, Black Lives Matter has become more than a series of events, but collective action and a social movement supported by many to bring attention and make change.

Individuals who act by participating in or being in solidarity with social movements have skin in the game or a self-interest to be involved. These people have a reason for making sacrifices and changes to day-to-day life in order to participate in a social movement for a common purpose (Tarrow, 2011). All the youth workers I spoke to identified some reason for acting in this situation. 
The youth workers had a powerful desire to use current information as a learning tool for the youth they work with. Vera used research and provided access to information to try to get her youth to care outside of themselves. She wanted them to "find when they were curious about different things happening so they could say 'I need to go and I need to have an opinion about this,' instead of saying 'I don't care"' (April 19, 2016). Timothy said Jamar Clark's death led his youth to understand more of why they were talking about race:

Those who previously didn't really get why we were talking about race, after Jamar Clark was shot, it was kind of like an 'oh, aha' moment for a lot of them ... [black] lives are not valued by the system as much as my life as a white person. It gave us an opportunity to talk about why we are social change makers and Christians (April 1, 2016).

Individuals who take part in movements frame their own story and reasons why they participate in contentious and disruptive politics. Participants must then define and construct a collective identity that has a distinct understanding of them and what distinguishes them from others. Members must do "emotion work" in order to recruit others by reflection and shaping of emotions (Tarrow, 2011). This work can legitimize a movement in order to bring others into the collective understanding of a particular movement.

Youth workers were creating spaces to have their youth reflect and find connections to what was happening in Minnesota. Nate, who works with youth who have been in contact with police - some of whom knew Jamar Clark—stated, "They understood that there is this oppressive system holding black people down in Minneapolis,... but I don't think they understood that they could help change it" (Nate, April 4, 2016).

The sheer proximity to the movement affected other youth in north Minneapolis to take action. Nyame, who has been working with a research team on the topic of health disparities related to over-policed communities stated:

We had tried to get them to protest before, but [they didn't] until it hit close to home. Then they were like: it's not about Ferguson, it's not about Florida, it's not about New York, it's about everywhere.... When it hit close to home, it changed their passion and what affects them and their community. (April 4, 2016) 
These important moments and reflections help youth feel connected to a larger moment, where even if they are not directly involved, they are further able to navigate what their connection is to the cause of Black Lives Matter. Candice stated, "This year was really a year where it's been brought to the forefront... and students are aware and they're calling it out and it's about time" (June 14, 2016).

The status quo holds power and social movements disrupt that power. The status quo provides a definition for what is considered legitimate (Piven \& Cloward, 1977). We live and work within institutions that have the power to bring people together within movements by creating a sense of cohesion so that collective action can occur. Institutions can use the same forces to disperse us. Our roles within institutions can provide strategic opportunities for action as well as forces to maintain the status quo (Piven \& Cloward, 1977). Within the institution of the church, Timothy felt that it was very meaningful to his youth that they joined other churches in the area for a march and worship service, an opportunity they may not have found as meaningful otherwise (April 1, 2016).

\section{The Factors: Context, Identity and Worldview}

\section{Identity}

Our identity can shape much of who we are and how we see the world. Our identity can represent so much to a young person through our interactions, intentionally or not. As a white straight female who grew up in a suburban context and graduated from college, my identity and experiences can be very different from the youth I work with. Candice described the importance of having a similar identity and set of experiences as her students:

Being African-American, being a person of color...and knowing that there is a need here in Minnesota in particular for students to see someone that looks like myself... I have empathy because ... I come from Minneapolis Public School District and I know that there is a need for students of color... to have support" (June 14, 2016).

Candice also mentioned that similar to her students, she comes from a lower income background, qualified for free and reduced lunch, has siblings who did not graduate from high school, and was a first generation college student. 


\section{Experiences}

As youth workers, each of us has a unique set of experiences that shape our identity, the work we do and how we see the world. As humans we are heavily shaped by our lived experiences and what we are exposed to, which in turn shape our worldview. Our social position in society can also dictate our experiences and exposure. Even if our identity and experiences are similar to our young people's, it is false to assume that our youth have the same worldview as we have. Each generation develops new perspectives and ideas about the world; youth workers' understanding of the context and experiences of their youth will be different from the young people's understanding, especially if the youth workers are from outside the youths' community. Nate saw this with his young people: "Even if they weren't engaged in the protesting...their understanding of what's going on...they know.... And they are like genuinely afraid, genuinely this is real....I don't have to stand on the corner and worry about being shot" (April 4, 2016). Timothy recognized this with his youth that went to school in a predominately white school district versus a more diverse urban school (April 1, 2016).

\section{Personal and Professional Role}

I don't feel like it was outside of what I should do...but in general...our job as work force coaches, we are supposed to help them with employment education, but we spend most of our time doing case management and mentoring...because how can you talk about employment when they witnessed someone get shot or... when they have nowhere to stay at night?...Even if I knew they weren't ready for [a job], we had to push them in that direction because that is what we were supposed to be doing. (Nate, April 4, 2016)

As professionals, youth workers need to balance their personal commitments and professional role. I struggled with this personally due to my vested interest in action and change. Yet, I wondered, what freedom and constraints do I have in my professional role? Do others struggle with this tension? This question is central to this article: Who or what are you accountable to? Your values? Your youth? Your organization leadership? The broader community? Ideally we want to pay attention to all of those things, but what do you do in your role when those are in tension? Youth workers in direct service are often closer to the young people in an organizational system, but not always in roles where we can make structural changes or decisions. Often those who do not have as much power can be at the center of such changes 
(Tarrow, 2011). In a professional position, youth workers must struggle to balance the needs of young people with the expectations of their own job and organization. In moments of disruption, this is a balance a youth worker must strike. Some youth workers did not experience this tension:

I think if I were in a different church, [my personal and professional roles] would have clashed, but I think I am really lucky to be in this church... when people in the church find out I am going to marches...it's not so much a push back or tension, they're like 'Oh that's great, we're really glad you do those things and can bring them back to the youth.' (Timothy, April 1, 2016)

\section{Organizational Support}

Professional youth work positions are within organizations that exist in a setting that influences the organization's goals and strategies, environment, culture, structure, size and technology (Daft, 2010). Becker (1982) defined culture as the conventional understandings that are manifested where individuals have similar ways of acting in shared understanding and coordination. If the scope of a movement is outside the cultural understanding and commitment of an organization it can be difficult for a youth worker to have the autonomy to engage in the disruption in particular ways or at all.

This will look different in every organization in which cultural norms and understandings can influence how one will act. Five of the youth workers stated that they felt overall they were being supported in their work by their organization. Four of the five said there was not total support for the BLM cause or anti-racism work in their organization, questioning whether the organization was engaging as deeply as their young people, or if the youth workers had enough autonomy to take action as individuals, they did not see the overall organization as completely supportive. They did discuss new initiatives that have started to transform their organizations since the beginning of the national BLM movement in the form of creating statements, groups, discussions and initiatives.

Personally, yes... my boss was very supportive, I was able to get time off...in order to go to the protests. They were very open for me to come in my protest gear because at the time it was very cold...my smell of smoke...my baggy eyes from coming from [the fourth precinct]... they were supportive of me as an individual....I just think that in terms of organizationally, professionalness [sic], 
they didn't feel like they could show [support for Black Lives Matter]... We are going through a transition... where all of our work is going to be done with a racial equity lens...I think it was happening before Jamar Clark, but I definitely think the national movement had a [role] in reevaluating what we look like. (Nyame, April 4, 2016)

Timothy, who felt fully supported by his organization, discussed the long history of his organization being engaged with the Wounded Knee Trials in the 1960's and immigration reform. He said even though the focus on racism and Black Lives Matter is new, there is a long history of focus on justice. In contrast to all of the other youth workers, Candice discussed not feeling supported by her organization at first, but now she sees the institutional change resulting from ongoing participation with the students and the staff around this work:

I wanted to quit the first year because of the racism and discrimination that I experienced as a black woman myself, and I came in quietly and just did my job because I was there for the kids and I wanted to quit so many times.... But I now see that it was meant for me to be at least these three years, because now I see how change is taking place. (June 14, 2016)

\section{Context}

Organizations, youth and their families reside in particular contexts that can shape their opportunities, social interactions, and understanding of the world. Being at an organization that is located and works with youth in north Minneapolis, our context shapes what we see and experience. Within their families, young people are exposed to particular opportunities, power, privileges, barriers and discrimination (Witt, 2011). According to psychologist Urie Bronfenbrenner (1994) it is these direct interactions with family, peer groups, school, churches, neighborhoods and more that affect an individual's microsystem. Larger ecosystems such as youth-serving organizations, family, friends, mass media, and social services interact with the microsystem to impact the young person. Macrosystems are larger attitudes, ideologies and social institutions. Both the macrosystem and exosystem interact with the microsystem to impact the child. This is all a function of time, also known as the chronosystem (Bronfenbrenner, 1994). Bronfenbrenner's theory helps to remind us as youth workers that there are many systems at play affecting the life and context of a child. 
Both suburban youth and urban youth have systems that shape their experiences. An example is Nate's explanation of the difference in policing in north Minneapolis:
A [Latino] guy was dropping off his son...four cops pulled him
over, drew guns on him...I guess his car fit the description...and
he wrote this long post saying, this is real, this would not have
happened in any other part of Minneapolis, why is this OK to
happen in north Minneapolis...I think that is what people don't get
(April 4, 2016).

Stephanie said she has to find ways for those in her context to understand what is going on: "Our church has to go back to basic needs, to basic rights, to basic opportunities to even begin to have the conversation of people understanding this. I think sometimes that is so powerful for how basic we have to get for them to really understand again that we have issues" (April 21, 2016).

\section{Roles of Youth Worker in Response to Disruption}

Beyond the dynamics of one's context, worldview and experiences, youth workers found themselves in different roles to respond to this situation. Next I outline the roles that the youth workers I spoke to shared with me. They have a unique sense of what youth workers can offer to the young people with whom they work.

\section{Educator}

Many youth workers, especially in suburban environments, saw their primary role as that of educator. By sharing of information, stories and facilitating conversations, five youth workers created space for information sharing to dispel the myths and provide exposure to what is going on beyond the media. Stephanie said: "My role is to start conversation, to ask hard questions." (April 21, 2016). Storytelling was an essential part of how they portrayed what is going on. Youth workers have the opportunity to develop the capacity for young people to make choices within their growing sense of interdependence through forms of education. According to Gisela Konopka (1973), it is important that youth workers not impose values, but encourage an open discussion and the exchange of ideas. Timothy discussed the importance of education as an action:

I'm a big believer that education is a form of liberation and social change, and it's a form of action... when we have dialogue and we have discussions and we reflect on experiences, that is a form of action. Whereas my youth, when they think action they think of 
going to a march or building a house, which that is obviously action, but as far as race when it comes to social movements, especially for those of us who are white...our first step really needs to be intense education. (April 1, 2016)

\section{Mentor}

Youth workers in mentoring roles took the stance of accompanying youth in their personal journey in relation to what was happening. It also looked like being a listener. Many youth workers whose youth engaged in protest focused on equipping their youth with tools around direct action and facilitating safety. Nate's youth organization in north Minneapolis held a healing circle, led by members of the community, which is something they often do after a young community member dies (April 4, 2016). Often the youth workers were mentoring youth to see beyond themselves in any given situation. In mentoring relationships, young people have the opportunity to receive education, access to resources and power to cope with the system and pressures in which they find themselves (Konopka, 1973). In north Minneapolis, youth workers had to address both the personal ways the oppression affects their young people and the larger system. Nate discussed supporting a young person who was friends with Jamar, witnessed Jamar's death and was being sought as a witness:

He didn't want to talk at all. He didn't know who the cops were, who the defense lawyer was...he thought it was all bad.... They had to explain to him that they were for Jamar. Even after that he didn't believe they were for him... [We said] 'Don't you see, you should go and say what you saw.'... He didn't even see that because he thought everyone was bad and against him... The system is so oppressive that there is no trust in the system, even the good guys in the system...there is no trust. (April 4, 2016)

This direct work that is necessary for youth workers to be engaged in can look very different in different contexts. In suburban contexts, there are pressures and systems that create barriers for youth. From their perspective, the youth workers discussed the need to create a culture for the youth to know and learn more. The three youth workers whose youth were protesting saw this support as part of their mentoring role. Timothy stated, "Three youth in particular, I have had long conversations...about...what is direct action... what is non-violence, what is justice, and what is reconciliation...I have really been trying to get them to realize how complicated some of these things are" (April 1, 2016). 


\section{Facilitator of Relationships}

Since youth workers have strong relationships with young people, they have the opportunity to help facilitate and be a liaison for new relationships. Many youth workers in suburban settings identified the importance of facilitating diverse relationship-building, so that youth can understand more from their peers through retreats and events. These events often include both educational experiences and relational components. Stephanie discussed having a panel because, "You cannot argue with someone's story and humanizing people in their story" (April $21,2016)$. Other youth workers saw it as their role and opportunity to help youth more directly connected to the movement to make change by facilitating institutional relationships with community leaders, organizations, police, government and nonprofits to support them in making change.

\section{Faith Leader and Sharing in Vulnerability}

Three of the youth workers I interviewed worked at churches and were responsible for the faith formation of high schoolers. They saw faith as a crucial component to this topic. Even a youth worker who was not working in a faith setting stated:

The faith community I think has a much bigger role to play in connecting youth to the movement... the faith community has a platform - that people listen to the faith community - that they wouldn't listen to otherwise. They have a special role in providing a platform for youth voices to be heard. (Nate, April 4, 2016)

These youth workers played many roles, but in particular saw their opportunity to discuss these issues through a faith lens, which limited the potential tensions of their roles in their organizations. As one youth worker put it, as long as it had to do with Jesus, it was fair game. In a suburban context, it was new for their youth to have this discussion in a church setting, and it was really the youth director's leadership to say, "Yes, we can talk about this at church." Church can be a more comfortable or safe environment when discussing difficult issues. These youth workers had chance to push beyond their norm and be vulnerable with their youth. Stephanie said she had to "model what it looks like to understand... that I have privilege... to put language around it. My role is to be honest and vulnerable" (April 21, 2016).

\section{Facilitator of Action}

Some youth workers went further and provided ways for their youth to take action in the form of doing research, civic engagement, and direct action work. Facilitating action included giving 
youth the tools and confidence they needed to participate in these opportunities. Within youth work, there is great opportunity to allow young people to try out different roles and opportunities of accountability through participation and accountability. Youth workers can give young people a chance to engage as members of their community and understand what it means to be a citizen (Konopka, 1973, p. 9).

Youth workers I met with accomplished engaging youth in leadership through opportunities to be involved. Vera had her youth do research to open their eyes more. Nyame helped to support her youth in their participation in the protest at the police precinct and on the highway. They also did research at the events. She said: "Once they feel like they are ready [educated], it is our job to bring them there, so they can do the action" (April 4, 2016). In contrast, Timothy discussed that his youth wanted to be engaged in the community actions beyond what he was comfortable doing as a youth group, but supported them nonetheless:

For example, the Mall of America protest-I was uncomfortable with making that a youth group event, because there was legality issues, there were parents who need to be involved with some of these things... a lot of the youth were like, 'We have to do this,' which was a great energy...but that was one of the things that was hard for me, realizing they are minors, and getting them to understand my point of view with that, but I encouraged them if they wanted to go, go with your parents. (April 1, 2016)

There is accountability and responsibility for both the youth and youth workers that can create a learning opportunity by taking action together. Candice saw her role as facilitating peaceful actions and giving students peaceful ways to respond because she did not want to see them involved in violence or rioting. She shared peaceful tactics with the students and helped them organize sit-ins, peaceful protests and walkouts, and performance nights to share through music where they could take public action for the cause they were passionate about.

\section{Building Peer Leaders}

Many youth workers saw that by supporting their youth in these conversations and education, young people had the opportunity to be leaders among their peers, inside and outside of the organization. By having more information, youth are able to lead others, provide support, ask questions and push each other in understanding. For example, "When they're hearing someone that is saying 'All Lives Matter', they're able to say, 'Yes, but this is not what the hashtag 
means' and correctly explaining something" (Vera, April 19, 2016). As members of social movements, young people often are not given access to power or are tokenized within systems that do not authentically give them equal power, especially in bureaucracies (Konopka, 1973). It is our role to look out for this and help to support our young people in being leaders. Not all youth were taking leadership roles, but those who did discussed situations with youth and adults in partnership:

I have really empowered a couple of our youth to be a part of [the racial justice] group, not because the youth group isn't doing stuff [but] because I feel like they can do even more by being a part of that group and bring those ideas back to the youth group, which they have and that has been spectacular... I have really empowered them to be kind of the leaders of what the youth group does. (Timothy, April 1, 2016)

\section{Advocates for Institutional Change}

Youth workers who have direct contact with young people have a role as liaisons in a larger organization to be help support changes that will benefit their young people and also support a broader vision to the experiences of people within their organizations and communities. Youth workers can be positioned to identify the need:

My critique is...that you have a staff that is $60 \%$ white and $40 \%$ black and we serve a $100 \%$ African-American population...there is no facilitation about race... white supremacy, European thought verses African thought...or about power structure, there is a certain kind of tension amongst staff. (Nate, April 4, 2016)

Youth workers identified initiatives, committees, and policies they have either been a part of changing or would like to see change at their institutions. Candice participated in many larger institutional opportunities to make change "because of this discrimination I have seen against our students of color and students from within north Minneapolis and because of the whole issue of the achievement gap" (June 14, 2016). She also discussed how she has led trainings for other staff on how to work with African-American students, participated in the equity committee, been a member of a selection committees for new administrators, and supported students in asking and making institutional changes (June 14, 2016). Stephanie was looking to make change by digging deeper into areas yet untouched: 
I would even like our leadership to look more diverse and how that happens...Part of that is always thinking about we have such a diverse school and we are not diverse at all at our church. My role is not to be comfortable... not to be safe and lazy, [but] to dig in a little bit. (April 21, 2016)

\section{Where Do We Go from Here?}

The wide variety of roles and commitment to action by the youth workers I interviewed is inspiring. In exploring other people's stories, I discovered more about my own story. As a youth worker, I want to remain authentic to who I am, to the leadership of my youth, and the expectations of my organization and my community. When it becomes more personal and close to home, it can be a challenge to bring all of these things together. First of all, I want to make sure my youth have an outlet to talk about these issues and to know they are loved by a community to be exactly who they are and that their lives matter to our community despite the many systems that tell them that they do not matter.

When I was at the precinct, I saw the shooting of a protester by white supremacists and I saw young people grabbed and pepper-sprayed by police. I knew there were real risks from outsiders and police towards my youth, if they attended. I always personally felt safe because I was with people I knew who had my back, but in no way could I see it as my role to encourage youth under 18 to come to the protest. To those youth who did want to go or whom I saw there, I made sure to explain the risks and safety measures I hoped they would take.

Working in a church setting, I have been a part of a coalition of youth workers who put on a yearly justice-oriented retreat. This year's theme was Race, Racism and White Privilege. In this setting of urban and suburban churches I have struggled to figure out how to represent myself in this space, knowing that the work of justice directly affects an everyday reality for my youth. In trying to work in systems embedded with racism and white supremacy, even though this is what we were trying to discuss, my youth, I and other leaders saw ways that these characteristics were being reproduced through this retreat. Who is in control? Who is made comfortable? Who has put in the work? How do you encourage other white people to be OK with being uncomfortable? How can I act in partnership with others from different contexts, while making sure my youth get the most out of the experience? Are youth voices being heard and responded to? 
Despite the challenges, I was so proud of my youth because they found ways to celebrate themselves and each other through this experience. We had one of the most impactful retreats that we have ever had, and youth are still asking questions and bringing this information to their peers. For the adult leaders, I saw a transformation with white leaders from suburban contexts, finding ways to be better white allies by being role models for their youth when they pushed them to listen and be more vulnerable with each other. After seeing how different youth and adults reacted to the retreat in a number of ways, it made me question how we can live more in these tensions to get our youth to a new place and understanding.

From the interviews I conducted, I realized that all youth workers live with these tensions, and we must act with our heart and head with the community. The youth workers I interviewed had some powerful statements about who we are as youth workers.

I think youth worker is just another word for someone who gives and receives education... and someone who has to perform based on what they know. It is your mission to educate yourself...in order to educate them... In my eyes a youth worker's biggest role is to provide equipment...in order for them to feel ready for anything, anything that they are aiming towards. (Nyame, April 4, 2016)

In a youth position you're in quite a leadership position, even naming what is happening and making a stance, is powerful. Naming it as a problem and an injustice and then letting kids understand they have roles in that and responsibility... giving someone permission to care about something...is important (Stephanie, April 21, 2016).

Here are five concrete recommendations for people who work with and on behalf of young people to respond to disruption in their community:

1. See disruptions from social justice movements and other situations as a positive opportunity to engage our youth.

2. Engage in the tension that can be created in order to more authentically be ourselves and serve our young people and communities.

3. Continue to challenge systems of racism and oppression in all contexts. 
4. Act boldly in order to serve our young people.

5. Prepare youth to be engaged as citizens in the world and their context.

I hope this inspires other youth workers to be bold to act in times of disruption, and not just with the day-to-day work, because as youth workers, I truly believe our place is found in the "in-between" for our youth; between school and home life, between current situation and future aspirations, between peers and community. We have a huge role in engaging upcoming generations for all their leadership and possibilities.

\section{References}

Becker, H. (1982). Culture: a sociological view. In K. A. Tiemann (Ed.), The intersections collection (pp.1161-177). Boston, Massachusetts: Pearson Learning Solutions.

Bronfenbrenner, U. (1994). Ecological models of human development. International Encyclopedia of Education, 3(2). Oxford:Elsevier. Retrieved from http://www.psy.cmu.edu/ siegler/35bronfebrenner94.pdf

Daft, R. L. (2010). Organizational theory and design. Mason, Ohio: South-Western Cengage Learning.

Konopka, G. (1973). Requirements of healthy development of adolescent youth. Adolescence, $8(31), 1-26$. Retrieved from http://www.extension.umn.edu/youth/research/requirements-for-healthy-developmentof-adolescent-youth/index.html.

Piven, F. F., \& Cloward A. (1977). Poor people's movements. New York: Vintage House.

Tarrow, S. G. (2011). Power in movement. New York, NY: Cambridge University Press.

Witt, J. (2011). SOC. New York, NY: McGraw-Hill. 